\title{
Analysis Of Water Loss Efficiency Of Agricultural Harvest Reselts In Guakdale Irrigation Are Of Tuatuka Village, Kupang City, Province Of East Nusa Tenggara
}

\author{
Yunus Fallo ${ }^{1}$, Ramzy GGL. Sayonara, Anie Adrianti Tuati \\ \{yunus_fallo@yahoo.co.id, sayonararamzy@gmail.com, adrianti.tuati@gmail.com\} \\ Kupang State Polytechnic, Penfui, Kupang, Indonesia
}

\begin{abstract}
Agricultural development in Indonesia is still considered important from the overall development, especially to support the pace of the economy in general. Gaukdale Irrigation Area which has an area of 168.50 hectares of land located in the village of Tuatuka has the Gaukdale Irrigation Network that was built since the year 2000. The existence of damage from irrigation network infrastructure has resulted in water loss in the carrier channel, namely in the primary channel and secondary along with other completeness buildings, so that water entering the paddy field is not optimal. The percentage of damage to the BG-1 Primary Channels and BG-Ka Secondary Channels in the Guakdale Irrigation Network is $=8.39 \%$. The influence of channel damage on Carrier Channels in the Guakdale Irrigation Network experienced water loss, namely in the Primary Channel of $1.12 \mathrm{~m} 3 / \mathrm{sec}$ and on the Secondary Channel of $0.69 \mathrm{~m} 3 / \mathrm{sec}$.
\end{abstract}

Keywords : Damage to the channel, Loss of water, Damage Repair, Increased Agricultural Results

\section{Introduction}

In this time agricultural development in Indonesia is still considered important from the overall development, especially to support the pace of the economy in general [1]. This can be seen from the agricultural sector making a large contribution compared to other sectors on Indonesia's economic growth [2]. Water is a gift of God Almighty and one of the main elements for the survival of humans, animals and plants, besides there are other elements in supporting the continuity of human life [3].

The Province of East Nusa Tenggara (NTT), which consists of islands spread across several regions, is one of Indonesia's provinces that has a lot of land abandoned. In recent years the population has begun to cultivate abandoned land into productive land by being processed into agricultural land. The Government of East Nusa Tenggara with various efforts to improve agricultural output, in this case supporting facilities and infrastructure are needed to achieve these goals ..

In line with the direction and request of the Governor of East Nusa Tenggara, when harvesting hybrid corn Nasa 29 varieties in Oesao delivered by the Head of the Department of Agriculture (Kadis) of NTT, the Governor asked the farmers to use abandoned land during the dry season. The question of water availability can be done with technological engineering (Pos Kupang, Wednesday, 17 October 2018) 
Gaukdale Irrigation Area which has an area of 168.50 hectares of land located in the village of Tuatuka, East Kupang Subdistrict, Kupang Regency has the Gaukdale Irrigation Network that was built since the 2000s, the Gaukdale Irrigation Network Area is mostly not able to operate properly due to a lot of damage to the carrier channels due to the age of the building is long enough also due to the growth of vegetation and human activity. Thus resulting in water loss in the carrier channel, namely the primary and secondary channels along with other completeness buildings, so that the water entering the paddy field is not optimal.

To meet basic needs and make it maintain the existence of Kupang Regency rice barns and increase population growth and increase in per capita consumption per year, a number of efforts by the Government in addition to opening new agricultural land, also improve the effectiveness and efficiency of existing agricultural land. In this case the maintenance of irrigation networks is one of the activities to prevent damage due to operations and natural processes. Maintenance work both prevention and prevention will not end. Several factors cause the severity of the damage, due to the way of maintaining and operating the facilities and infrastructure.

Judging from the problems above, it is necessary to have a study on, Assessment of the Percentage of Water Damage and Loss in the Gaukdale Irrigation Area, Tuatuka Village, Kupang Regency, East Nusa Tenggara Province, to be recommended by the authorities to solve the problem and improve irrigation network buildings so that the agricultural land area of 168.50 hectares can be irrigated well, evenly and adequately in the future can increase agricultural yields that increase. The formulation of the problem in this study

- How much is the loss of water in the Guakdale Irrigation Network with the existing condition?

- How to overcome the loss of water in the cross section of the channel to meet water needs to increase agricultural output?

- How much does it cost to deal with water losses in the channel section in the Kupang District Guakdale Irrigation network?

The outputs of the results of this study to be achieved are:

- Knowing the loss of water in the cross section of the channel whose water is needed to irrigate rice fields in Tuatuka Village, Kupang Regency from year to year is always lacking water for the needs of plants in the paddy fields

- Knowing the costs required to overcome water losses in the channel section in the Kupang District Guakdale Irrigation network

- Scientific publications through journals that will be published for information purposes for similar researchers

\section{Research Methods}

\subsection{Research sites}

The location of this research is in the Village of Tuatuka, East Kupang District, Kupang Regency, East Nusa Tenggara Province with an area of $350 \mathrm{Ha}$, which is geographically located at coordinates $10^{\circ} 9^{\prime} 30.53$ "LS and $123^{\circ} 50$ '53.10" BT. 


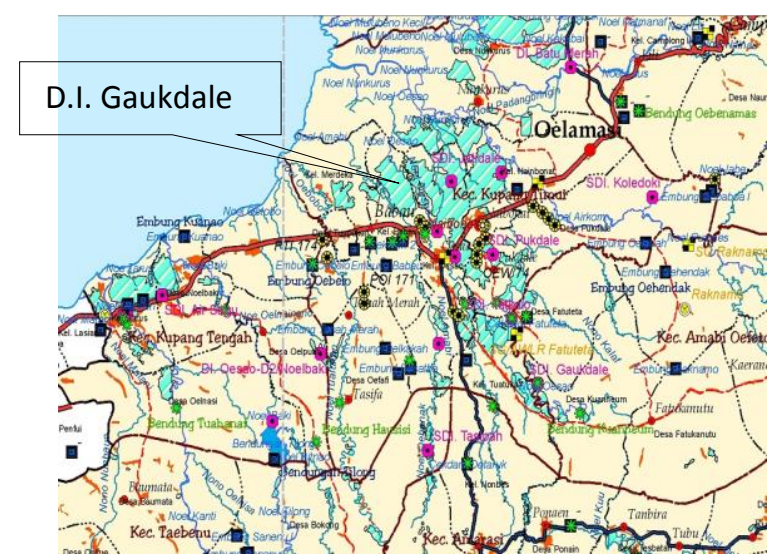

Fig. 1. Research Location

\subsection{Research Steps}

The initial step in this study is to collect references used as a basis in research related to water resources, which is important in a work related to resources is to calculate the loss of water debit and calculate the costs used to restore the condition of infrastructure as before (initial design) [4]. Next, carry out a survey and investigation in the field in the Guakdale Irrigation Network, through measurements of both the condition of the infrastructure and the water level in each channel section.

The research steps and data required are as follows :

- Irrigation Network Scheme

- Survey and Field Investigations, including

○ Measurement of Primary and Secondary Channel Lengths

- Measurement of each damage in the Primary and Secondary Channels

- Measurement of water level in each channel exists

- Water velocity measurement for the existing condition of each channel.

- Calculation of water speed according to initial design

- Calculation of water discharge needed for each field

- Calculation of water discharge required for all irrigated paddy fields

- Calculate water loss in each channel.

- Calculate the overall loss of water in the Guakdale irrigation network.

- Inventory each damage.

- Calculate the volume according to the inventory damage results

- Plan the costs needed to repair the damage in order to return each cross section of the channel that can hold the water needed to irrigate paddy fields in the Guakdale Irrigation Area 


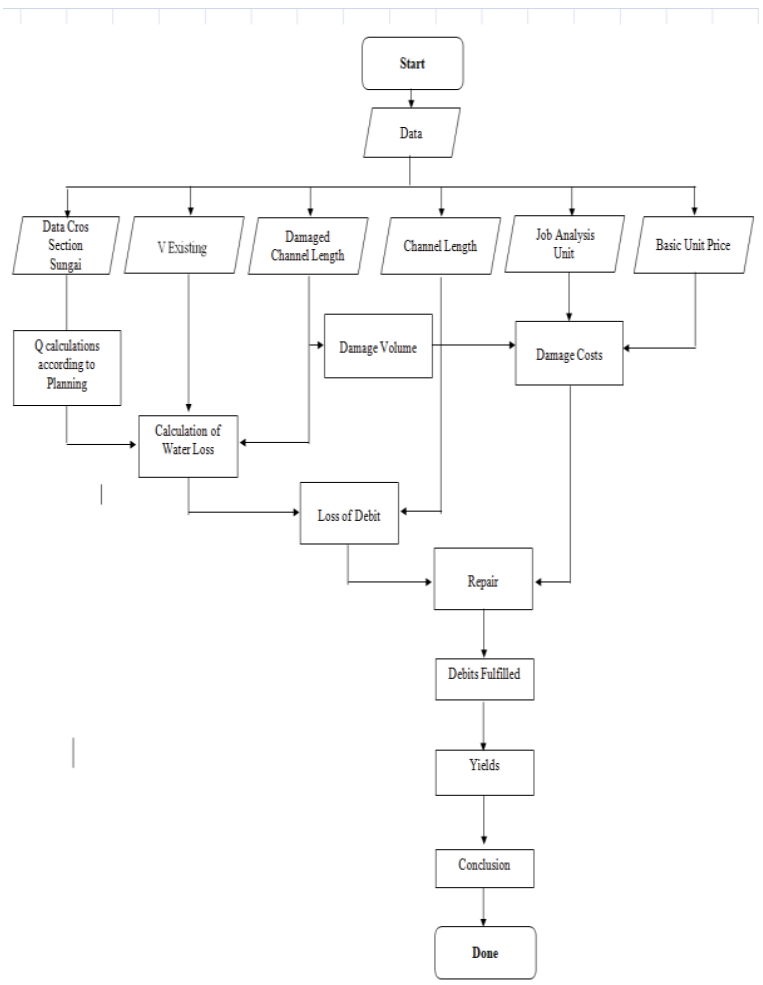

Fig. 2. Flow Chart (Research Flow Chart)

\section{Discussion}

\subsection{Identification of Irrigation Network Channel Conditions}

The Gaukdale irrigation area is used by the local community for rice fields by utilizing water from the Gaukdale weir. The Gaukdale irrigation area was built in 2003 and is one of the areas where most of the irrigation network cannot operate properly due to lack of community attention.

The activity of identifying channel conditions on D.I Gaukdale begins tracking from the intake to the secondary channel, the condition of the channel is a couple channel, but in some locations damaged, leakage, vegetation, and cracks.

After visual identification of the existing network location, the malfunction or nonoptimality is caused by the age of the building and natural factors that have been around for a long time and eventually caused many damaged channels to occur so that the loss of water entering the paddy field is not optimal [5].

The survey and identification of the condition of irrigation canal networks in D.I Gaukdale, Tuatuka Subdistrict, Kupang District was carried out by tracing irrigation channels starting from primary to secondary channels and the condition of the channels in the form of couple channels. The results of the survey and identification of existing conditions in the field 
in the irrigation network in D.I Gaukdale, Tuatuka, Kupang District are presented in the Figure and Table below

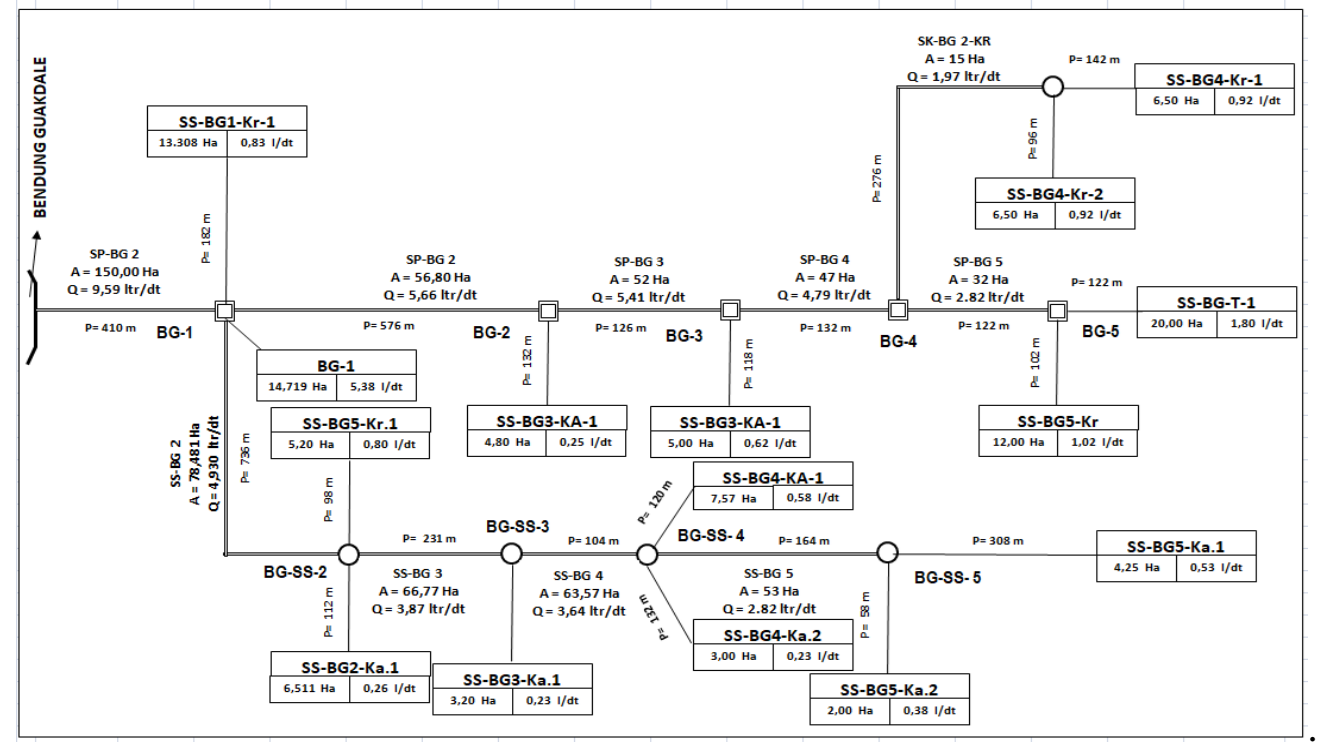

Fig. 3 Scheme of Kupang District's Guakdale Irrigation Network Source: Nusa Tenggara River Basin II, 2019

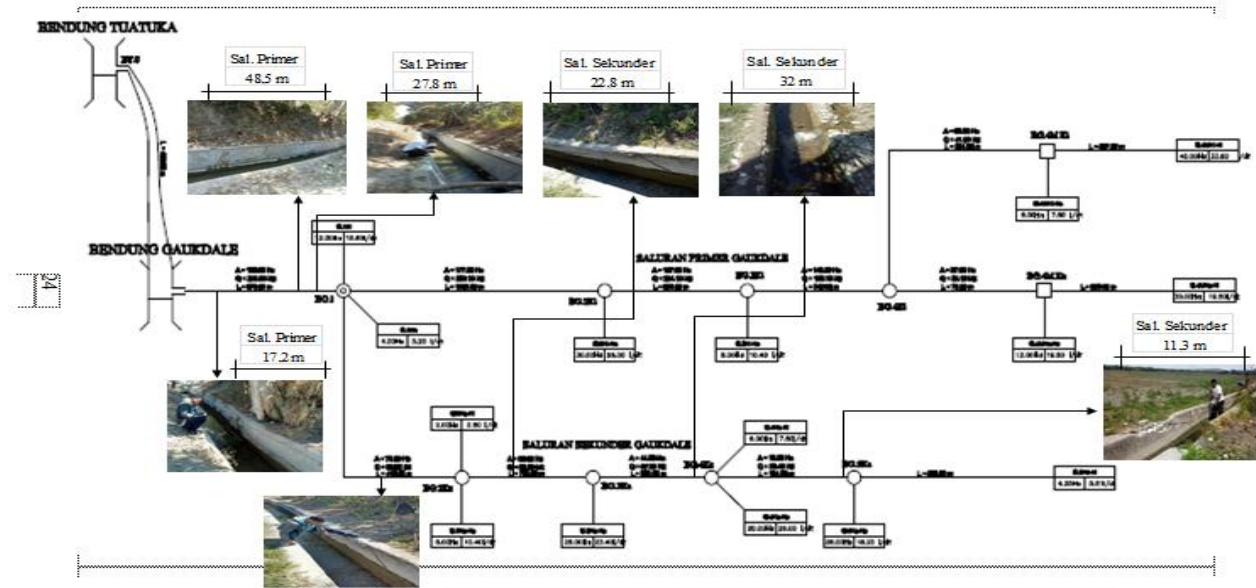

Fig. 4: Location of Damage in the Gaukdale Irrigation Network in Kupang Regency Source: Survey Results and Field Identification, 2019

The results of the survey and measurement and identification of the field obtained data about the existing condition of the channel, the following is presented in Table 5.3 below

Table 1. Existing Conditions of Length and Damage in Primary and Secondary Irrigation Networks in Gaukdale 


\begin{tabular}{|c|c|c|c|c|}
\hline \multirow{4}{*}{ No } & \multirow[b]{3}{*}{ Nama Saluran } & \multirow{3}{*}{$\begin{array}{c}\text { Panjang } \\
\text { Saluran }\end{array}$} & \multicolumn{2}{|c|}{ Hasil Survey Lapangan } \\
\hline & & & \multicolumn{2}{|c|}{ Panjang Saluran } \\
\hline & & & Kondisi Baik & Kondisi Rusak \\
\hline & & $(\mathrm{m})$ & $(\mathrm{m})$ & $(\mathrm{m})$ \\
\hline 1 & 2 & 3 & 4 & 5 \\
\hline I & Saluran Primer & & & \\
\hline & Saluran Primer BG-1 & 670.00 & 606.30 & 63.70 \\
\hline & Jumlah Panjang Saluran Primer BG-1 & 670.00 & 606.30 & 63.70 \\
\hline II & Saluran Sekunder & & & \\
\hline 1 & Saluran Sekunder BG - $2 \mathrm{Ka}$ & 410.00 & 391.30 & 18.70 \\
\hline 2 & Saluran Sekunder BG - $3 \mathrm{Ka}$ & 736.00 & 713.20 & 22.80 \\
\hline 3 & Saluran Sekunder BG - $4 \mathrm{Ka}$ & 231.00 & 167.00 & 64.00 \\
\hline 4 & Saluran Sekunder BG - $5 \mathrm{Ka}$ & 104.00 & 92.70 & 11.30 \\
\hline & Jumlah Saluran Sekunder BG-Ka & $1,481.00$ & $1,364.20$ & 116.80 \\
\hline & Jumlah Total Pengamatan Saluran & $2,151.00$ & $1,970.50$ & 180.50 \\
\hline
\end{tabular}

Source: Survey and Measurement Results, 2019

\subsection{Calculation of Damage Percentage in Primary and Secondary Channels in the Gaukdale Irrigation Network}

From the results of the survey and measurement and identification of the field presented in Table 5.3, the next percentage of damage can be calculated in each channel, namely the primary and secondary channels according to field observations. Observations were made on BG-1 Primary Channels and BG-Ka Secondary Channels with a length of 2,151 m

The basic calculation of the percentage of each channel is as follows:

a. BG-1 Primary Channel percentage calculation::

Length of BG-1 Primary Channel $=670,00 \mathrm{~m}$

The condition of the channel is still in good condition $=576,50 \mathrm{~m}$

Damaged channel condition

$$
=63,70 \mathrm{~m}
$$

Percentage of Damage $=\frac{\text { length of damage }}{\text { channel length }} \times 100 \%$

Percentage of Damage $=\frac{63,70}{670,00} \times 100 \%$

Percentage of Damage $=10,51 \%$

b. BG-2 Primary Channel percentage calculation::

Length of BG-2 Primary Channel $=1.481,00 \mathrm{~m}$

The condition of the channel is still in good condition $=1.364,20 \mathrm{~m}$

Damaged channel condition

$$
=116,80 \mathrm{~m}
$$

Percentage of Damage $=\frac{\text { length of damage }}{\text { channel length }} \times 100 \%$

Percentage of Damage $=\frac{116,80}{1.481,00} \times 100 \%$

Percentage of Damage $=5,43 \%$

According to the calculation results in the form of the table above, the percentage of damage to the BG-1 Primary Channel in the Gaukdale Irrigation Network is $=10.51 \%$ of the length of the channel $=670.00 \mathrm{~m}$, and the damage to the BG-Ka Secondary Channel is = $5.43 \%$ of the length of the Secondary Channel $=1,481 \mathrm{~m}$. From observations and calculations on BG-1 Primary Channels and BG-Ka Secondary Channels in the Gaukdale Irrigation Area 
with a total length of 2,151.00 m channels with good conditions along 1,970.00 $\mathrm{m}$ and in damaged conditions along $180.50 \mathrm{~m}$. The calculation results presented in Table 2 of the existing conditions in BG-1 Primary Channels and BG-Ka Secondary Channels experienced a damage percentage of $=8.39 \%$.

For further calculations presented in the form of Table 2.

Table 2 Calculation of Damage

\begin{tabular}{|c|c|c|c|c|c|c|}
\hline \multirow{4}{*}{ No } & \multirow[b]{3}{*}{ Nama Saluran } & \multirow{3}{*}{$\begin{array}{l}\text { Panjang } \\
\text { Saluran }\end{array}$} & \multicolumn{2}{|c|}{ Hasil Survey Lapangan } & \multicolumn{2}{|c|}{ Prosentase } \\
\hline & & & \multicolumn{2}{|c|}{ Panjang Saluran } & \multicolumn{2}{|c|}{ Saluran } \\
\hline & & & Kondisi Baik & Kondisis Rusak & Baik & Rusak \\
\hline & & (m) & $(\mathrm{m})$ & $(\mathrm{m})$ & $(\%)$ & $(\%)$ \\
\hline 1 & 2 & 3 & 4 & 5 & 6 & 7 \\
\hline \multicolumn{7}{|c|}{\begin{tabular}{l|l} 
I & Saluran Primer \\
\end{tabular}} \\
\hline & Saluran Primer BG-1 & 670.00 & 606.30 & 63.70 & 90.49 & 10.51 \\
\hline & Jumlah Panjang Saluran Primer BG-1 & 670.00 & 606.30 & 63.70 & 90.49 & 10.51 \\
\hline \multicolumn{7}{|c|}{\begin{tabular}{l|l|l} 
II & Saluran Sekunder \\
\end{tabular}} \\
\hline & Saluran Sekunder BG - $2 \mathrm{Ka}$ & 410.00 & 391.30 & 18.70 & 18.19 & 0.87 \\
\hline & Saluran Sekunder BG - $3 \mathrm{Ka}$ & 736.00 & 713.20 & 22.80 & 33.16 & 1.06 \\
\hline & Saluran Sekunder BG - $4 \mathrm{Ka}$ & 231.00 & 167.00 & 64.00 & 7.76 & 2.98 \\
\hline & Saluran Sekunder BG - $5 \mathrm{Ka}$ & 104.00 & 92.70 & 11.30 & 4.31 & 0.53 \\
\hline & Jumlah Saluran Sekunder BG-Ka & $1,481.00$ & $1,364.20$ & 116.80 & 63.42 & 5.43 \\
\hline & Jumlah Total Pengamatan Saluran & $2,151.00$ & $1,970.50$ & 180.50 & 91.61 & 8.39 \\
\hline
\end{tabular}

Source: Survey and Measurement Results, 2019

\subsection{Analysis of Causes of Primary and Secondary Canal Damage in the Gaukdale Irrigation Network}

The results of the identification and analysis of the causes of damage and the calculation of the percentage of damage to the BG-1 Primary Channels and BG-Ka Secondary Channels with a channel length of $2,151.00 \mathrm{~m}$ are as follows:

1. Percentage of damage in BG-1 Primary Channels and Secondary Channels in the Guakdale Irrigation Network $=8.39 \%$

2. In accordance with Regulation of the Minister of Public Works No. 43 of 2007 stating "the age of building construction is no longer than 10 years can be done damage identification survey" thus needs to be repaired in accordance with the regulations specified Light Damage

3. Further improvement is needed in connection with damage that occurs in the walls of the channel which causes the drainage system to malfunction and reduces the flow of water in the drainage channel to drain water into the rice fields to be diary. 


\subsection{Calculation of Debit Loss in Each Channel Section BG-1}

Calculation of discharge loss in each channel required a water velocity (V) data that occurs according to the existing conditions (field) [5]. Observations were made with pimpong balls released in the upstream part made with each distance of $10 \mathrm{~m}$, while to see the flow velocity was carried out with stofwatt [6]. The results of surveys and observations in the field on the Channels are divided into 3 Segments, each segment is observed as many as 5 experimental data [7], as for the data presented in the Table below:

According to a source from the Nusa Tenggara River Basin Agency (BWS) of Nusa Tenggara that according to the initial planning for the water velocity (V) on the channel crossing on BG Primary Channel 1 is $=1.50 \mathrm{~m} / \mathrm{sec}$ and on the cross section of the channel at Secondary BG.2Ka, BG.3Ka, BG.4Ka and BG.5Ka sections is $=1.20 \mathrm{~m} / \mathrm{sec}$

Table 3. Debit Calculation (Q) and Debit Loss in each BG Primary Channel BG-1

\begin{tabular}{|c|c|c|c|c|c|c|c|c|c|}
\hline \multirow{3}{*}{ No } & \multicolumn{4}{|c|}{ Conditions According to Planning } & \multicolumn{4}{|c|}{ Existing Condition } & \multirow{3}{*}{$\begin{array}{l}\text { Loss of Water } \\
\text { Discharge } \\
\text { m3/seconds }\end{array}$} \\
\hline & Wide (b) & High (T) & Water Speed $(V)$ & Water Discharge & Wide (b) & $\operatorname{High}(\mathrm{T})$ & Water Speed (V) & Water Discharge & \\
\hline & (m) & (m) & $\mathrm{m} / \mathrm{seconds}$ & $\mathrm{m} 3 /$ seconds & (m) & (m) & $\mathrm{m} / \mathrm{sec}$ nds & $\mathrm{m} / \mathrm{seconds}$ & \\
\hline 1 & 2 & 3 & 4 & 5 & 6 & 7 & 8 & 9 & 10 \\
\hline \multirow[t]{8}{*}{ I } & \multicolumn{2}{|l|}{ Segment - 1} & & & & & & & \\
\hline & \begin{tabular}{|r|}
1.00 \\
\end{tabular} & 1.00 & 1.50 & 1.500 & 1.00 & 0.44 & 1.38 & 0.61 & 0.89 \\
\hline & 1.00 & 1.00 & 1.50 & 1.500 & 1.00 & 0.44 & 1.46 & 0.64 & 0.86 \\
\hline & 1.00 & 1.00 & 1.50 & 1.500 & 1.00 & 0.44 & 1.46 & 0.64 & 0.86 \\
\hline & 1.00 & 1.00 & 1.50 & 1.500 & 1.00 & 0.44 & 1.30 & 0.57 & 0.93 \\
\hline & 1.00 & 1.00 & 1.50 & 1.500 & 1.00 & 0.44 & 1.40 & 0.62 & 0.88 \\
\hline & \multicolumn{3}{|r|}{ Amount of Debit } & 7.500 & & & & 3.08 & 4.42 \\
\hline & \multicolumn{3}{|c|}{ Average Discharge } & 1.500 & & & & 0.62 & 0.88 \\
\hline \multirow[t]{8}{*}{ II } & \multicolumn{2}{|l|}{ Segment - 2} & & & & & & & \\
\hline & 1.00 & 1.00 & 1.50 & 1.500 & 1.00 & 0.39 & 1.25 & 0.49 & 1.01 \\
\hline & 1.00 & 1.00 & 1.50 & 1.500 & 1.00 & 0.39 & 1.26 & 0.49 & 1.01 \\
\hline & 1.00 & 1.00 & 1.50 & 1.500 & 1.00 & 0.39 & 1.26 & 0.49 & 1.01 \\
\hline & 1.00 & 1.00 & 1.50 & 1.500 & 1.00 & 0.39 & 1.25 & 0.49 & 1.01 \\
\hline & 1.00 & 1.00 & $\begin{array}{r}1.50 \\
\end{array}$ & 1.500 & 1.00 & 0.39 & 1.25 & 0.49 & 1.01 \\
\hline & \multicolumn{3}{|c|}{ Amount of Debit } & 7.500 & & & & 2.45 & 5.05 \\
\hline & \multicolumn{3}{|c|}{ Average Discharge } & 1.500 & & & & 0.49 & 1.01 \\
\hline \multirow[t]{8}{*}{ III } & \multicolumn{2}{|l|}{ Segment - 3} & & & & & & & \\
\hline & 1.00 & 1.00 & 1.50 & 1.500 & 1.00 & 0.33 & 1.19 & 0.39 & 1.11 \\
\hline & 1.00 & 1.00 & 1.50 & 1.500 & 1.00 & 0.33 & 1.19 & 0.39 & 1.11 \\
\hline & 1.00 & 1.00 & 1.50 & 1.500 & 1.00 & 0.33 & 1.19 & 0.39 & 1.11 \\
\hline & 1.00 & 1.00 & 1.50 & 1.500 & 1.00 & 0.33 & 1.10 & 0.36 & 1.14 \\
\hline & 1.00 & 1.00 & 1.50 & 1.500 & 1.00 & 0.33 & 1.19 & 0.39 & 1.11 \\
\hline & & & Amount of Debit & 7.500 & & & & 1.93 & 5.57 \\
\hline & & & verage Discharge & 1.500 & & & & 0.39 & 1.11 \\
\hline
\end{tabular}

Source: Calculation Results of This Research 
Table 5. Discharge Calculations (Q) and Debit Losses in Respectively on Secondary Channels BG.2Ka, BG.3Ka, BG.4Ka and BG.5Ka Sections

\begin{tabular}{|c|c|c|c|c|c|c|c|c|c|}
\hline \multirow{3}{*}{ No } & \multicolumn{4}{|c|}{ Conditions According to Planning } & \multicolumn{4}{|c|}{ Existing Condition } & \multirow{3}{*}{$\begin{array}{l}\text { Loss of Water } \\
\text { Discharge } \\
\mathrm{m} 3 / \mathrm{seconds} \\
\end{array}$} \\
\hline & Wide (b) & $\operatorname{High}(T)$ & Water Speed $(\mathrm{V})$ & Water Discharge & Wide (b) & $\operatorname{High}(T)$ & Water Speed $(V)$ & Water Discharge & \\
\hline & (m) & (m) & $\mathrm{m} / \mathrm{seconds}$ & $\mathrm{m} 3 /$ seconds & (m) & (m) & $\mathrm{m} / \mathrm{seconds}$ & $\mathrm{m} / \mathrm{seconds}$ & \\
\hline 1 & 2 & 3 & 4 & 5 & 6 & 7 & 8 & 9 & 10 \\
\hline I & \multicolumn{3}{|c|}{ Segment Secondary Channels BG-2 Ka } & & & & & & \\
\hline 1 & $\begin{array}{r}0.80 \\
\end{array}$ & 0.80 & 1.20 & 0.77 & 0.80 & 0.27 & 1.01 & 0.22 & 0.55 \\
\hline 2 & 0.80 & 0.80 & 1.20 & 0.77 & 0.80 & 0.27 & 0.01 & 0.22 & 0.55 \\
\hline 3 & 0.80 & 0.80 & 1.20 & 0.77 & 0.80 & 0.27 & 1.00 & 0.22 & 0.55 \\
\hline 4 & 0.80 & 0.80 & 1.20 & 0.77 & 0.80 & 0.27 & 1.00 & 0.22 & 0.55 \\
\hline 5 & 0.80 & 0.80 & 1.20 & 0.77 & 0.80 & 0.27 & 1.01 & 0.22 & 0.55 \\
\hline & \multicolumn{3}{|r|}{ Amount of Debit } & 3.84 & & & & 1.09 & 2.75 \\
\hline & \multicolumn{3}{|c|}{ Average Discharge } & 0.77 & & & & 0.22 & 0.55 \\
\hline II & \multicolumn{3}{|c|}{ Segment Secondary Channels BG-3 Ka } & & & & & & \\
\hline 1 & 0.80 & 0.80 & 1.20 & 0.77 & 0.80 & 0.22 & 0.91 & 0.16 & 0.61 \\
\hline 2 & 0.80 & 0.80 & 1.20 & 0.77 & 0.80 & 0.22 & 0.91 & 0.16 & 0.61 \\
\hline 3 & 0.80 & 0.80 & 1.20 & 0.77 & 0.80 & 0.22 & 0.91 & 0.16 & 0.61 \\
\hline 4 & 0.80 & 0.80 & 1.20 & 0.77 & 0.80 & 0.22 & 0.91 & 0.16 & 0.61 \\
\hline 5 & 0.80 & 0.80 & 1.20 & 0.77 & 0.80 & 0.22 & 0.91 & 0.16 & 0.61 \\
\hline & \multirow{2}{*}{\multicolumn{3}{|c|}{ Amount of Debit }} & 3.84 & & & & 0.80 & 3.04 \\
\hline & \multirow{2}{*}{\multicolumn{3}{|c|}{$\begin{aligned} \text { Average Discharge } \\
\text { Segment Secondary Channels BG-4 Ka }\end{aligned}$}} & 0.77 & & & & 0.16 & 0.61 \\
\hline III & & & & & & & & & \\
\hline 1 & 0.80 & 0.80 & 1.20 & 0.77 & 0.80 & 0.19 & 0.88 & 0.13 & 0.63 \\
\hline 2 & 0.80 & 0.80 & 1.20 & 0.77 & 0.80 & 0.19 & 0.88 & 0.13 & 0.63 \\
\hline 3 & 0.80 & 0.80 & 1.20 & 0.77 & 0.80 & 0.19 & 0.78 & 0.12 & 0.65 \\
\hline 4 & 0.80 & 0.80 & 1.20 & 0.77 & 0.80 & 0.19 & 0.78 & 0.12 & 0.65 \\
\hline \multirow[t]{3}{*}{5} & 0.80 & 0.80 & 1.20 & 0.77 & 0.80 & 0.19 & 0.78 & 0.12 & 0.65 \\
\hline & \multirow{2}{*}{\multicolumn{3}{|c|}{ Amount of Debit }} & 3.84 & & & & 0.62 & 3.22 \\
\hline & & & & 0.77 & & & & 0.12 & 0.64 \\
\hline IV & \multicolumn{3}{|c|}{\begin{tabular}{|c|} 
Average Discharge \\
Segment Secondary Channels BG-5 Ka \\
\end{tabular}} & & & & & & \\
\hline 1 & \begin{tabular}{|r|} 
\\
\end{tabular} & 0.80 & 1.20 & 0.77 & 0.80 & 0.11 & 1.38 & 0.12 & 0.65 \\
\hline 2 & 0.80 & 0.80 & 1.20 & 0.77 & 0.80 & 0.11 & 1.46 & 0.13 & 0.64 \\
\hline 3 & 0.80 & 0.80 & 1.20 & 0.77 & 0.80 & 0.11 & 1.46 & 0.13 & 0.64 \\
\hline 4 & 0.80 & 0.80 & 1.20 & 0.77 & 0.80 & 0.11 & 1.30 & 0.11 & 0.65 \\
\hline \multirow[t]{3}{*}{5} & 0.80 & 0.80 & 1.20 & 0.77 & 0.80 & 0.11 & 1.40 & 0.12 & 0.64 \\
\hline & \multirow{2}{*}{\multicolumn{3}{|c|}{$\begin{array}{r}\text { Amount of Debit } \\
\text { Average Discharge }\end{array}$}} & 3.84 & & & & 0.62 & 3.22 \\
\hline & & & & 0.77 & & & & 0.12 & 0.64 \\
\hline
\end{tabular}

Source: Calculation Results of This Research

Table 6. Calculation of Debit Loss in Primary Channels BG 1

\begin{tabular}{|c|c|c|c|c|}
\hline \multirow{3}{*}{ No } & \multirow{3}{*}{ Pengamatan } & Planning & Existing & \multirow{2}{*}{$\begin{array}{c}\text { Loss of Water } \\
\text { Discharge }\end{array}$} \\
\hline & & \multicolumn{2}{|c|}{ Water Discharge } & \\
\hline & & \multicolumn{2}{|c|}{$(\mathrm{Q}=\mathrm{m} 3 / \mathrm{seconds})$} & $(\mathrm{Q}=\mathrm{m} 3 / \mathrm{seconds})$ \\
\hline 1 & Segment 1 & 1.50 & 0.62 & 0.88 \\
\hline 2 & Segment 2 & 1.50 & 0.49 & 1.01 \\
\hline \multirow[t]{3}{*}{3} & Segment 3 & 1.50 & 0.39 & 1.11 \\
\hline & & \multicolumn{2}{|r|}{ Amount } & 3.01 \\
\hline & & \multicolumn{2}{|r|}{ Average } & 1.00 \\
\hline
\end{tabular}

Source: Calculation Results of This Research

From the results of calculations and observations in the field the loss of discharge (Q) on the BG 1 Primary Channel section is $1.00 \mathrm{~m} 3 / \mathrm{sec}$.

Table 7. Calculations (Q) and Debit Losses in Respectively on Secondary Channels BG.2Ka, BG.3Ka, BG.4Ka and BG.5Ka Sections 


\begin{tabular}{|c|c|c|c|c|}
\hline \multirow{3}{*}{ No } & \multirow{3}{*}{ Pengamatan } & Planning & Existing & \multirow{2}{*}{$\begin{array}{c}\text { Loss of Water } \\
\text { Discharge }\end{array}$} \\
\hline & & \multicolumn{2}{|c|}{ Water Discharge } & \\
\hline & & \multicolumn{2}{|c|}{$(Q=m 3 /$ seconds $)$} & $(Q=m 3 /$ seconds $)$ \\
\hline 1 & Segment Secondary Channels BG-2 Ka & 1.20 & 0.22 & 0.98 \\
\hline 2 & Segment Secondary Channels BG-3 $\mathrm{Ka}$ & 1.20 & 0.16 & 1.04 \\
\hline 3 & Segment Secondary Channels BG-4 Ka & 1.20 & 0.12 & 1.08 \\
\hline \multirow[t]{3}{*}{4} & Segment Secondary Channels BG- $5 \mathrm{Ka}$ & 1.20 & 0.12 & 1.08 \\
\hline & & \multicolumn{2}{|r|}{ Amount } & 3.19 \\
\hline & & \multicolumn{2}{|r|}{ Average } & 1.06 \\
\hline
\end{tabular}

Source: Calculation Results of This Research

Table 7. Budget Plan for Repair of Primary and Secondary Damage Repair in Guakdale

\begin{tabular}{|c|c|c|c|c|c|c|}
\hline No & Channel Name & Type of work & Volume & Unit & Unit Price & Total Price \\
\hline & & & & & $(\mathrm{Rp})$ & $(\mathrm{Rp})$ \\
\hline \multirow[t]{6}{*}{ I } & Primary Channels BG-1 & & & & & \\
\hline & Damage Length & & 63.70 & $\mathrm{M}$ & & \\
\hline & & Demolition work & 25.48 & M3 & $184,575.00$ & $4,702,971.00$ \\
\hline & & Couples work River Stone $(1: 4)$ & 25.48 & M3 & $833,241.17$ & $21,230,985.01$ \\
\hline & 3 & Couples work plastering Work $(1: 4)$ & 95.18 & M2 & $74,970.00$ & $7,135,644.60$ \\
\hline & & & & \multicolumn{2}{|r|}{ Sub Amount (I) } & $33,069,600.61$ \\
\hline \multirow[t]{10}{*}{ II } & Secondary Channels BG-Ka & & & & & \\
\hline & \begin{tabular}{|l|} 
Damage Length \\
\end{tabular} & & 116.8 & $\mathrm{M}^{\mathrm{T}}$ & & \\
\hline & & Demolition work & 30.37 & M3 & $184,575.00$ & $5,605,542.75$ \\
\hline & 2 & Couples work River Stone $(1: 4)$ & 30.37 & M3 & $833,241.17$ & $25,305,534.33$ \\
\hline & & Couples work plastering Work $(1: 4)$ & 134.32 & $\mathrm{M} 2$ & $74,970.00$ & $10,069,970.40$ \\
\hline & & & & \multicolumn{2}{|r|}{ Sub Amount (II) } & $40,981,047.48$ \\
\hline & & & & \multicolumn{2}{|r|}{ Amount (I+II) } & $74,050,648.09$ \\
\hline & & & & & PPN $10 \%$ & $7,405,064.81$ \\
\hline & & & & & Amount & $81,455,712.90$ \\
\hline & & & & & Rounded up & $81,455,000.00$ \\
\hline
\end{tabular}

Source: Calculation Results of This Research 


\section{Conclusion}

Based on the results of calculations, data analysis and discussion, the following conclusions can be drawn:

1. Influence of canal damage on the Carrier Channels in the Guakdale Irrigation Network suffers from water loss namely in the Primary Channel of $1.00 \mathrm{~m} 3 / \mathrm{sec}$ and on the Secondary Channel of $0.69 \mathrm{~m} 3 / \mathrm{sec}$

2. Ways to overcome the water loss in the channel section to meet the water needs to increase agricultural output needs to be carried out further improvements in connection with damage that occurs in the channel wall that causes the drainage system to function less and reduce the water flow in the drainage channel to drain water into rice fields that will be diary

3. Costs required to overcome water losses in the cross section of the channel in the Kupang District Guakdale Irrigation network are IDR 81.455.000

\section{References}

[1] Aninomous, (1986), Direktorat Jenderal Pengairan Standar Perencanaan Irigasi. Departemen Pekerjaan Umum, CV Galang Persada Bandung.

[2] Aninomous ( 2006) Direktorat Jenderal Pengairan, Kriteria Perencanaan Jaringan Irigasi, KP-01, Bandung, CV.Galang. Bandung.

[3] Anonimous, ( 2013) Analisa Harga Satuan Pekerjaan (AHSP) - Sumber Daya Air ( SDA) Kementrian PU, Jakarta

[4] Darajat, dkk (2010), Analisis Efisiensi Saluran Irigasi di Daerah Irigasi Boro Kabupaten Purworjo, Provinsi Jawa Tengah, Jurnal Pasca Sarjana Teknik Sipil UGM, Yogyakarta

[5] Gandakoesuma.R, (1981).Arti Irigasi Pada Umumnya. CV.Galang Persada, Bandung.

[6] Mawardi, Erman. (2007). Desain Hidrolik Bangunan Irigasi. PT. Alvabeta. Bandung.

[7] Sumadiyono Agus (2010), Analisis Efisiensi Pemberian Air di Jaringan Irigasi Karau Kabupaten Barito Timur Provinsi Kalimantan Tengah, Jurnal Fakultas Tehnik Sipil dan Lingkungan, Institut Tehnologi Bandung 